Apidologie, 1987, 18 (1), 43-52

\title{
DISTRIBUTION OF BROOD AND FOOD STORES IN COMBS OF THE HONEYBEE, APIS MELLIFERA L.
}

\author{
Kedar BUDATHOKI * and David S. MADGE ** \\ * Lumle Agricultural Centre, Pokhara, Gandaki Anchal, Nepal \\ ** Department of Biological Sciences, Wye College, University of London, \\ Ashford, Kent TN25 5AH, U.K.
}

\begin{abstract}
SUMMARY
The amount and distribution of honey, pollen, and brood in combs in honeybee (Apis mellifera L.) single-chambered hives having different shapes (side walls sloping $0^{\circ}-40^{\circ}$ ) and sizes were examined.

In small hives less honey was stored in the combs per unit area than in larger hives. The shape of the hives had no effect on the amount of honey stored but in small hives bees reared proportionally more brood than in larger ones.

Bees stored more honey in the upper horizontal sector of combs, irrespective of comb size and shape. Brood was reared in the lower horizontal sector of combs in hives with side walls sloping at $0^{\circ}$ and $10^{\circ}$ and in the central horizontal sector in combs of hives sloping at $20^{\circ}$ to $40^{\circ}$.

Brood was reared and more pollen stored in the central vertical sector of combs, irrespective of comb size. Honey was located at the sides of the comb, particularly in hives with side walls sloping at $0^{\circ}$ and $10^{\circ}$.

Honey was stored in cells along the top edge of the comb, irrespective of the slope of the side walls of the hive; pollen was stored along the sides of the comb, while the lower edge or sides of the comb was used for rearing brood.
\end{abstract}

\section{INTRODUCTION}

Worker bees in a honeybee colony collect nectar and pollen which are either utilized immediately or stored in the cells of combs and used later. The cells used for storing honey and pollen and those used for rearing brood are located in different areas of the same comb. The cells used for storing honey are often deeper than those used for storing pollen or rearing worker brood. Drone brood are reared in larger cells than those used for rearing worker brood (FrEe, 1977 ; ButLer, 1975). 
During the active season, worker brood occupy a semi-circular area in the comb. The cells on either side and above the brood are used for storing pollen and beyond this area honey is stored or the cells remain empty. Drone cells are located along the base and corners of the combs (FreE, 1977).

In this work the amounts and distribution of honey, pollen, and brood in combs in hives of different sizes and shapes were studied.

\section{MATERIALS AND METHODS}

The experiments were conducted at an apiary at Rothamsted Experimental Station in Harpenden, Hertfordshire. The hives used were single-chambered, half-size $(0.5$ B.S.) British standard, British standard (1.0 B.S.) size, and onc-and-a-half size British standard (1.5 B.S.). The shape of each type (size) of hive was altered by modifying two sides of different hives to slope at angles of 0 (control), 10 , 20, 30, and 40 degrees from the vertical. There were thus five hives of each type, each with differentlysloping sides. Each hive contained 10 or 11 top bars, the undersides of which being initially smeared with bees' wax to act as comb guides for the bees.

Swarms of Italian honeybees (Apis mellifera L.) were collected at random and one swarm was introduced into each hive. A small piece of comb $(3 \mathrm{~cm} \times 3 \mathrm{~cm})$ containing brood was fastened to the central top bar to prevent the swarm from absconding. When the bees completed comb building in $60-75$ days the combs were removed from the hives and both faces of each comb were photographed, using standardized procedures (BudatHoKı, 1985 ; BUDATHOKI and MadGE, 1987). The photographic transparencies of each comb were then projected onto a screen marked with a graduated grid (sector area : $3 \mathrm{~cm} \times 3 \mathrm{~cm}$ each) and the overall, horizontal and vertical distribution of cells containing honey, pollen, and brood in the combs were measured. Empty cells were also noted. Further details are given later. Where possible, the results were analyzed by analysis of variance.

\section{RESULTS}

\section{1) Overall distribution of stores and brood in combs}

The distribution of honey, pollen, brood, and empty cells in combs of different sizes in hives with side walls of varying slopes is summarized in Table 1.

The amount of stored honey was comparatively greater in combs in the 1.5 B.S. hives than in either the 0.5 B.S. or 1.0 B.S. hives. The amount of stored honey increased linearly with increasing angles of slope of side walls of hives (i.e. decreasing area of hives and combs) with all sizes $\left(F_{1.8}=14.90\right.$; $\mathbf{P}=<0.01)$. Although the proportion of pollen and brood generally diminished with increasing angle of slope of side walls in the 0.5 B.S. and 1.0 B.S. hives, the results were not significant; in the 1.5 B.S. hive the angle of slope had little effect on the amounts of pollen and brood. The smaller the hive and the steeper the sides of the hive wall, the less filled were the combs. There were more empty cells in the vertical $\left(0^{\circ}\right)$ combs than in the angled combs $(\mathrm{P}=<0.01)$. 


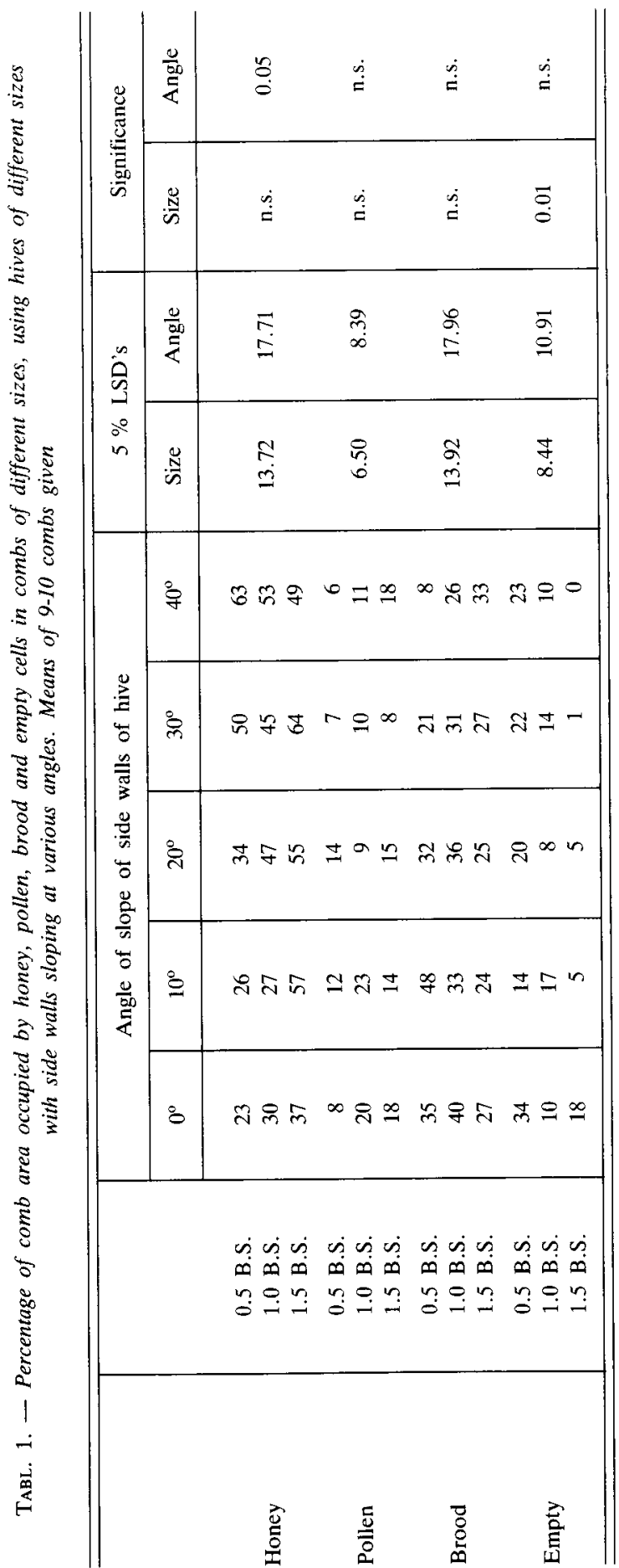


2) Horizontal distribution of stores and brood in combs

The horizontal distribution of honey, pollen, and brood in combs in 1.0 B.S. hives with sides sloping from $0^{\circ}$ to $40^{\circ}$ was determined by assessing the area occupied by them in three equal horizontal sectors of a grid, each $6 \mathrm{~cm}$ deep, placed over each face of the combs (Fig. 1). Empty comb areas were also recorded.
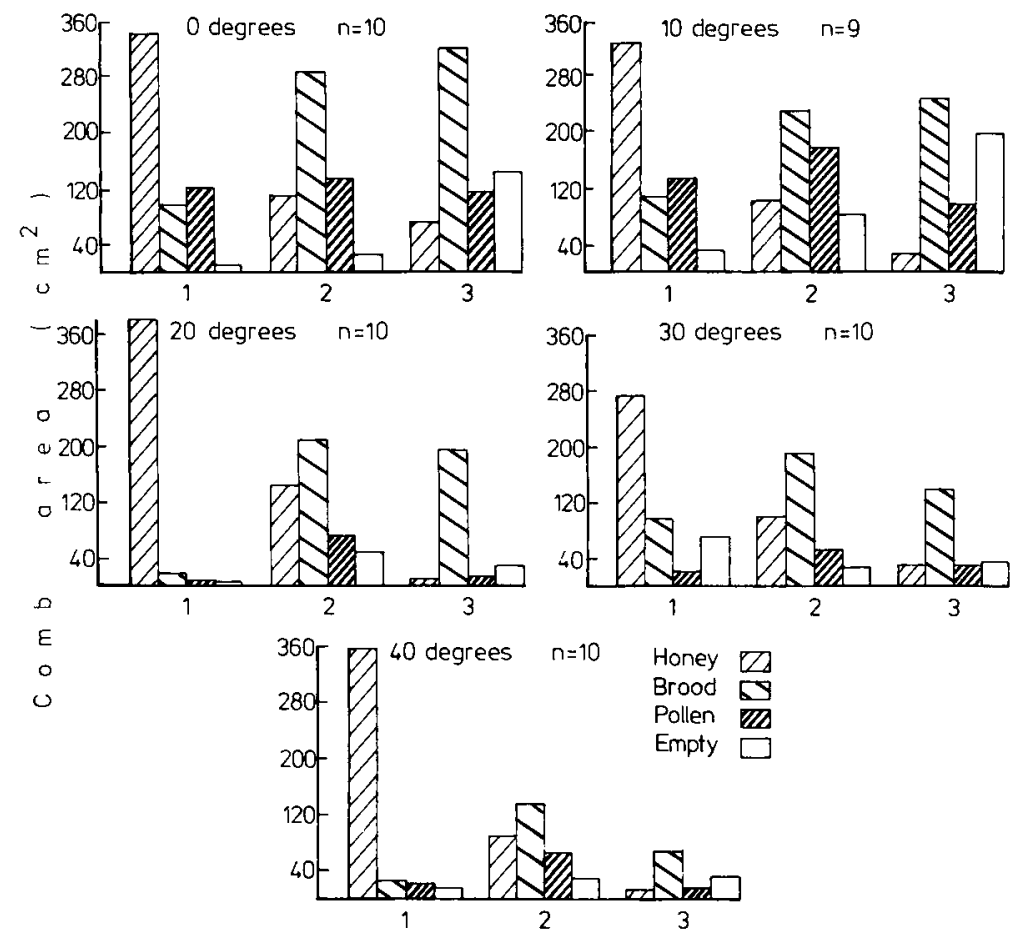

Fig. 1. - Horizontal distribution of food stores, brood and empty cells in the upper, central, and lower sectors of combs in British standard hives with side walls sloping at different angles.

$1:$ upper $6 \mathrm{~cm}, 2$ : central $6 \mathrm{~cm}, 3:$ lower $6 \mathrm{~cm}(\mathrm{n}=$ number of combs)

Honey. The amount of honey stored was much greater in the upper than in the central and lower horizontal sectors of the combs and more honey was stored in the central horizontal sector than in the lower one. The distribution of honey was generally unaffected by the slope of the hive side walls.

Pollen. More pollen was stored in the central horizontal sector of the combs, irrespective of the angles of slope of the hive side walls.

Brood. In hives with side walls sloping at $0^{\circ}$ and $10^{\circ}$ more brood was reared in the lower than in the central horizontal comb sector while only little 
brood was found in the upper horizontal sector. When the angle of slope of the hive side walls varied from $20^{\circ}$ to $40^{\circ}$ more brood was reared in central than lower horizontal sector of the combs and, again, only a small amount was found in the upper horizontal sector.

\section{3) Vertical distribution of stores and brood in combs}

The vertical distribution of stores and brood in combs in 1.0 B.S. hives with sides sloping from $0^{\circ}$ to $40^{\circ}$ was determined by placing a grid consisting of 11 equal vertical sectors over each face of the combs, the depth of each sector depending on the steepness of slope of the hive side walls (Fig. 2).

Honey. In hives with vertical $\left(0^{\circ}\right)$ side walls more honey was stored in the sides of the combs in the centre. With side walls sloping at $10^{\circ}$ or more the vertical distribution of honey was generally evenly distributed although tending to decrease towards the sides of the combs.
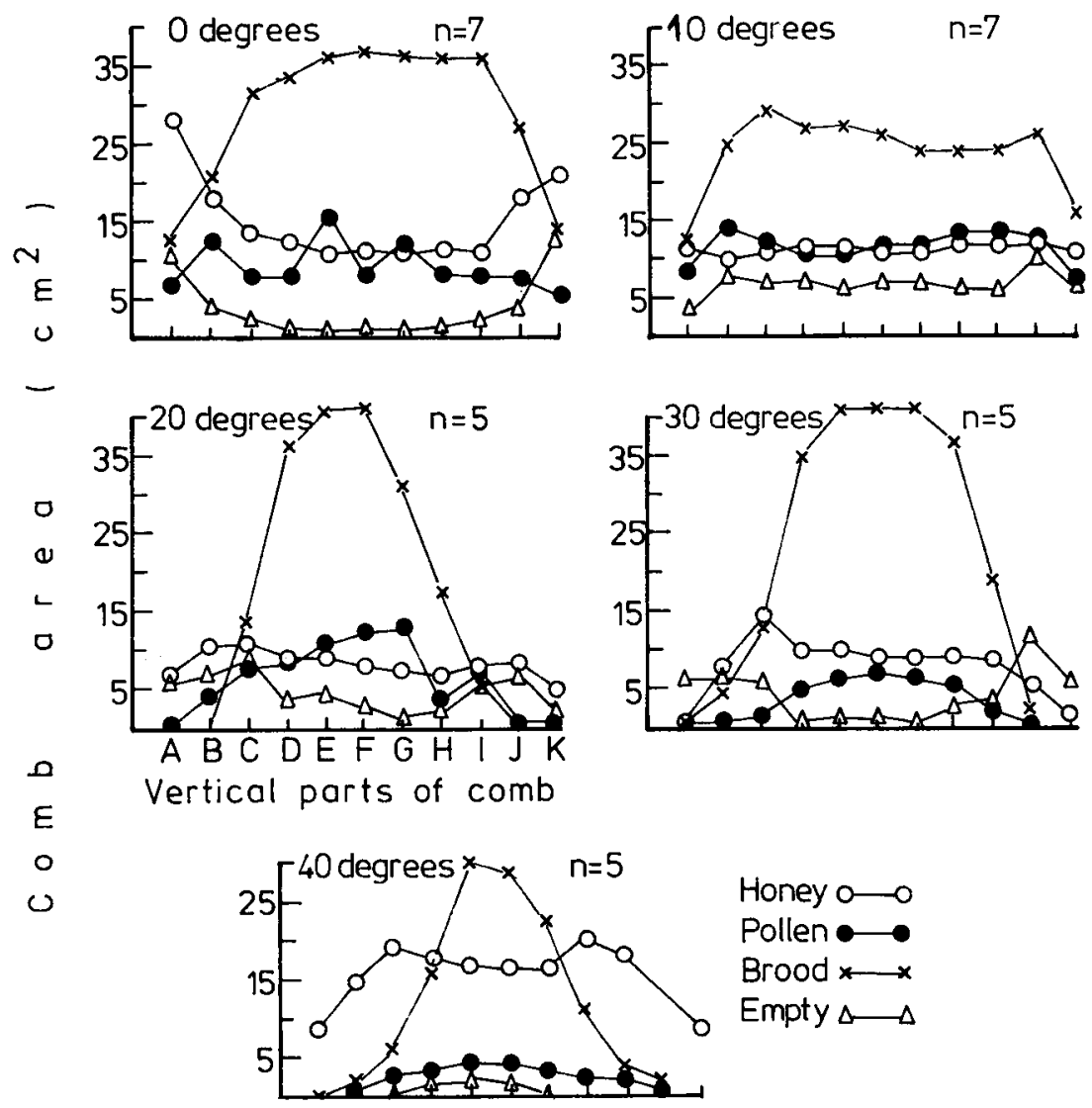

FIG. 2. - Vertical distribution of food stores, brood, and empty cells in combs in British standard hives with side walls sloping at different angles. A-K : vertical sectors of comb, in $3 \mathrm{~cm}$ strips 
Pollen. The distribution of pollen stored in different vertical sectors of the combs increased with increased brood in the central area of the comb and decreased with decreased brood at the sides of the comb, irrespective of the slope of the hive side walls.

Brood. More brood was located in the central vertical region than at the sides of the combs in hives with angled side walls, particularly in those with slopes varying from $20^{\circ}$ to $40^{\circ}$.

4) Distribution of stores and brood along the edges of combs

The effects of angle of slope of the side walls on the distribution of stores and brood along the four edges (width $3 \mathrm{~cm}$ ) of both faces of combs in 1.0. B.S. hives with sides sloping from $0^{\circ}$ to $40^{\circ}$ were studied; the length of the edges varied depending on the slope of the side walls (Fig. 3).

Generally, the cells at the upper edge of the combs and along the top bar were used largely for storing honey, irrespective of the slope of the side walls

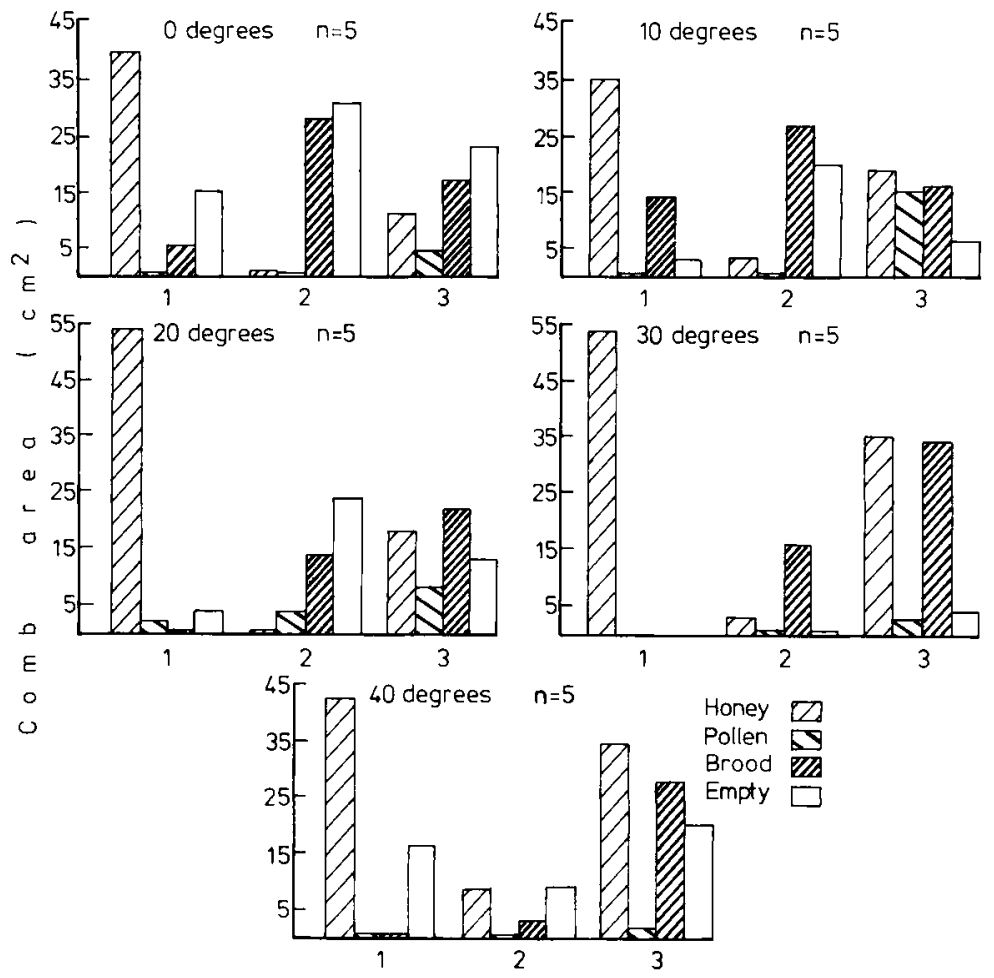

Fig. 3. - Distribution of food stores, brood, and empty cells along the outer edges of combs in British standard hives with side walls sloping at different angles. 1: upper edge, 2 : lower edge, $3:$ side edges (each $3 \mathrm{~cm}$ deep) $(\mathrm{n}=$ number of combs) 
of the hive. In contrast, pollen was mainly stored along the edges of the two sides of the combs. Although the lower edge of the combs was used mainly for brood rearing in hives with angles of slope of side walls at $0^{\circ}$ and $10^{\circ}$, in hives sloping at $20^{\circ}$ to $40^{\circ}$ the side edges were mainly selected for brood rearing.

\section{DISCUSSION}

Under natural conditions honeybee colonies build one or more vertical parallel combs containing hexagonal worker and drone cells (BUTLER, 1975). Worker cells are used for rearing worker brood and storing both honey and pollen while drone cells are used mainly for rearing drone brood although they can also be used for storing honey in the absence of worker cells (FREE and Williams, 1974).

The area of comb specific for a particular role depends on the honeybee colony's need, its location, and time of year. However, the same cells in a comb may be used at different times for food storage and brood rearing (BUTLER, 1975 ; FreE, 1977). In present experiments, during nectar flow and production of surplus honey, the proportion of comb area used by bees for storing honey generally increased with increasing size of the colony and angle of slope of the side walls of the hive. In small hives with a limited comb area, bees stored relatively less honey in their combs compared with standard and larger hives with increased comb area. Hence, providing that the hives are not too small to accommodate the incoming nectar, honey stored in the combs is not affected by the shape or slope of the side walls of the hive.

Bees in small hives are reluctant to store ample honey mainly because bees receiving nectar loads from nectar bee collectors do not find empty cells in which cells to store the incoming nectar. Thus, nectar gatherers have difficulty in passing on their nectar to house bees and will change to pollen collection or other activities (FREE, 1977), thus reducing the collection of nectar from the field which, in turn, diminished honey stored in small hives.

In double-chambered hives honeybees store surplus honey in combs in the food chamber while little honey is stored in the brood chamber (ButLer, 1975). Any stored honey in the brood chamber is used mainly for feeding young bees and larvae. In contrast, in single-chambered hives bees will store honey, pollen, and rear brood in the same comb and occupy a greater area of comb than that occupied by brood or pollen, although combs containing only honey are also commonly found in these hives. Such ample honey stores may be necessary for surviving either winter or the dearth period. Seeley and MORSE (1976) found that under natural conditions honeybees used about half 
of the total comb area built by bees for food storage and a quarter for brood rearing; present results broadly agreed with these conclusions.

In single-chambered hives bees tend to store more honey in the upper area of the brood comb than in either the central or lower areas which are filled by stored pollen and brood. The heavy honey in the upper area of the comb along the top bar and the lighter pollen and brood below may minimise stress and balance of weight within the comb (SEeley and MorSe, 1976). In present experiments, brood was mainly reared in the lower sector of the comb in hives with vertical or near vertical side walls. When the area of comb was reduced in hives with side walls sloping at $20^{\circ}$ or more the central area was used mainly for brood rearing in all sizes of hives. The vertical distribution of brood was hemi-spherical or square-shaped in hives with side walls sloping at $0^{\circ}$ or $10^{\circ}$ respectively, and with hive walls sloping at $20^{\circ}$ or more the brood area was bell-shaped.

Generally, bees in small ( 0.5 B.S.) or standard (1.0 B.S.) hives reared more brood per bee than bees in larger (1.5 B.S.) hives, confirming the observation by FreE and RACEY (1968) who suggested that pheromones produced by the queen encouraged worker bees to rear more brood. Although large honeybee colonies reared less brood per bee than small colonies, they produced more brood compared with smaller ones. Owing to the smaller needs for brood rearing (nursing duties by worker bees) per bee, larger colonies have a higher proportion of bees available for nectar gathering and pollen collection. The honey produced per bee is also greater in large colonies.

Bees stored pollen mainly in the central area of the comb owing to the large amount of brood there, confirming observations by FreE (1967), TODD and Reed (1970), and Al-Tikrity et al. (1972), who all concluded that the amount of pollen collected by a colony was related to the amount of brood in it. FreE and Williams (1975) also found that the amount of stored pollen and brood in colonies were correlated. However, the amount of pollen stored is not necessarily the same as the amount of pollen brought in daily by bees since the rate of utilization of pollen may be less and possibly exceed the rate at which pollen is collected from the field (Jeffree and Alleen, 1957).

\section{ACKNOWLEDGEMENTS}

We thank Dr J.B. Free for his cooperation. We are grateful to $D^{r}$ R.E. Kempson for statistical advice, Mr. Andrew Ferguson for technical assistance, and Miss Jackie Simpkins for photographic help. K.B. received financial assistance from the Overseas Development Administration (British Council). 


\section{RÉSUMÉ \\ REPARTITION DU COUVAIN ET DES PROVISIONS DE NOURRITURE DANS LES RAYONS DE L'ABEILLE, APIS MELLIFICA L.}

1. Des recherches ont été faites sur la quantité et la répartition du couvain et des provisions de nourriture chez l'abeille, Apis mellifica, dans des ruches, et donc des rayons, de taille et de forme différentes. Les ruches utilisées comportaient un seul corps, de taille variable : $1 / 2$ fois la norme britannique, norme britannique normale, 1 fois $1 / 2$ la norme britannique, et contenaient toutes 10 à 11 cadres vides à barrette supérieure. La forme des ruches était modifiće de telle sorte que les deux côtés de chaque ruche fassent un angle de 0 (témoin), 10, 20, 30 et $40^{\circ}$ avec la verticale. Un essaim d'abeilles était introduit dans chaque ruche et 60 à 75 jours plus tard on estimait la répartition des provisions, du couvain et des cellules vides en photographiant les deux faces de chaque cadre et en projetant les négatifs sur une grille graduée dans des conditions standardisées.

2. Plus la ruche est grande et forte la pente des parois latérales, plus la quantité de miel stocké dans les rayons est élevée par unité de surface (Tabl. 1). La quantité de pollen et de couvain diminue lorsque l'angle des parois latérales augmente. Les résultats varient pourtant énormément.

3.1. Répartition horizontale : dans des ruches de norme britannique avec différentes inclinaisons des parois latérales, il y a plus de miel dans les portions supéricures des rayons que dans les portions centrales et inférieures et légèrement plus de pollen dans les portions centrales des rayons, quelle que soit la pente des parois (Fig. 1). Le couvain est élevé dans les portions inférieures des rayons, dans les ruches qui ont des parois faiblement inclinées, et dans les portions centrales des rayons, lorsque la pente des parois est plus forte.

3.2. Répartition verticale : le miel est généralement réparti d'une façon uniforme dans les ruches de norme britannique avec diverses inclinaisons des parois latérales, mais il est plus grandement stocké sur les bords des rayons lorsque la pente des parois est forte $\left(0\right.$ ou $\left.10^{\circ}\right)$ (Fig. 2). Le pollen et le couvain se trouvent plus dans les portions centrales des rayons, surtout dans les ruches à parois fortement inclinées.

3.3. La partie supérieure des rayons est utilisée pour stocker le miel, quelle que soit la forme des parois de la ruche (Fig. 3). Le pollen est stocké principalement le long des bords sur les deux côtés des rayons. Le couvain est élevé principalement le long du bord inférieur des rayons dans les ruches à parois fortement inclinées et sur les bords des rayons dans les ruches à parois plus faiblement inclinées.

4. On a aussi étudié la répartition des provisions et du couvain dans des rayons alternativement en plastique et en cire, dans des ruches à norme britannique et à parois latérales verticales. Les abcilles stockent le pollen, élèvent le couvain et pondent dans les rayons en cire et non dans les rayons en plastique, tandis que le miel est principalement stocké dans les rayons en plastique.

\section{ZUSAMMENFASSUNG \\ VERTEILUNG VON BRUT UND FUTTERVORRÄTEN IN WABEN DER HONIGBIENE, APIS MELLIFERA L.}

1. Dic Verteilung und Menge von Brut und Futtervorräten der Honigbiene, Apis mellifera L., im Bienenstock und in Waben verschiedener Größe und Form wurde untersucht. Die verwendeten Bienenstöcke bestanden aus einem cinfachen Kasten folgender Größen : 1/2 British standard, normal British standard und 1 1/2 British standard, jeweils mit 10-11 oberen Leisten. Die Form der Bienenstöcke wurde so modifiziert, daß die beiden Seiten des Stocks um die Winkel $0^{\circ}$ (Kontrolle), $10^{\circ}, 20^{\circ}, 30^{\circ}$ und $40^{\circ}$ von der Vertikalen abwichen. Bienenschwärme wurden nach dem Zufallsprinzip auf die Stöcke verteilt und 60-75 Tage später die Verteilung von Futtervorräten, Brut und leeren Zellen geschätzt. Dazu wurden Fotos von beiden Sciten der Waben erstellt und der Film unter standarisierten Bedingungen auf ein graduiertes Gitter projeziert. 
2. Je größer die Ausdehnung des Bienenstocks und je steiler die Seitenwände, desto umfangreicher waren die Futtermengen pro Einheitsfläche in den Waben (Tab. 1). Obwohl die Menge an Pollen und Brut mit zunehmendem Winkel der Seitenwände (d.h. abnehmendem Stockvolumen) generell abnahm, variierten dic Ergebnisse stark.

3.1. Bei Verwendung von Bienenstöcken des Formats "standard British" mit verschiedenem Winkel der Seitenwände wurde mehr Honig horizontal in den oberen als in den zentralen und tieferen Bereichen der Bienenwaben eingelagert und zwar unabhängig vom Neigungswinkel der Seitenwände (Abb. 1). Dic Brut wurde bei Bienenstöcken mit schrägen Seitenwänden im unteren horizontalen Bereich der Waben aufgezogen und bei Stöcken mit steileren Seitenwänden im horizontal mittleren Bereich aufgezogen.

3.2. Der Honig war bei Bienenstöcken des Typs "standard British" mit verschieden schrägen Seitenwänden vertikal glcichmäßig in den Waben verteilt, jedoch wurde in Bienenstöcken mit steilen $\left(0^{\circ}\right.$ oder $10^{\circ}$ ) Seitenwänden mehr Honig in den Seiten der Waben eingelagert (Abb. 2). Im zentralen vertikalen Bereich der Waben - vor allem bei den steilen Formen der Bienenstöcke — wurde mehr Pollen und Brut gefunden.

3.3. Der obere Rand der Waben wurde für die Honiglagerung benutzt unabhängig von der Form der Seitenwände (Abb. 3). Pollen wurde entlang der seitlichen Ränder der Waben gelagert. Brut wurde bei Stöcken mit größerer Abschrägung entlang dem unteren Rand der Waben aufgezogen, bei geringerer Abschrägung entlang den beiden Seiten der Waben.

4. Die Verteilung von Futtervorräten und Brut auf Wachs- und Plastikwaben in abswechselnder Reihenfolge wurde ebenfalls untersucht, wobei britische Standardkästen mit vertikalen Seitenwänden benutzt wurden. In die Wachswaben lagerten die Bienen sowohl im Brut- wie im Honigraum Pollen ein, sie zogen Brut auf und es wurden Eier gelegt, aber nichts von dem geschah in Plastikwaben. Der Honig wurde aber vorzugsweise in Plastikwaben eingelagert (Tab. 2).

\section{REFERENCES}

Al-Tikrity W.S., Benton A.W., Hillman R.C. and Clarke J.R.W.W., 1972. - The relationship between the amount of unsealed brood in honeybee colonies and their pollen collection. J. Apic. Res., 11, 9-12.

BUDATHOKı K., 1985. - Studies on building and use of combs by honeybecs (Apis mellifera L.) with reference to hive design. M. Phil. thesis, University of London.

BudathoKı K. and MAdGE D.S., 1987. - Beekeeping using cold and warm way hives (Submitted for publication).

Butler C.G., 1975. - The honey-bee colony - life history. In : The Hive and the Honey Bee. Ed. by Dadant and Sons, pp. 39-74. Hamilton, Illinois.

FreE J.B., 1967. - The production of drone comb by honeybee colonies. J. Apic. Res., 6, 29-36.

FreE J.B., 1977. - The Social Organization of Honeybees. pp. 10-11. Edward Arnold, London.

Free J.B. and RaceY P.A., 1968. - The effect of size of honeybee colonies on food consumption, brood rearing and longevity of bees during winter. Entomol. exp. appl., 11, 241-249.

Free J.B. and Williams I.H., 1974. - Factors determining food storage and brood rearing in honeybee (Apis mellifera L.) comb. J. Entomol., 49, 47-63.

FrEe J.B. and Williams I.H., 1975. - Factors determining the rearing and rejection of drones by the honeybee colony. Anim. Behav., 23, 650-676.

Jefrree E.P. and Allen M.D., 1957. - The annual cycle of pollen storage by honeybees. J. Econ. Entomol., 50, 211-212.

Seeley T.D. and Morse R.A., 1976. - The nest of honeybee (Apis mellifera). Insectes soc., 23, 495-512.

Todd F.F. and REED C.B., 1970. - Brood measurement as a valid index to the value of honcybee as pollinators. J. Econ. Entomol., 63, 148-149. 